\title{
Banana somaclonal variation assessed by Amplified Fragment Length Polymorphism profiles at early cycles of in vitro culture
}

\author{
Ermini, J. L., Tenaglia, G. C., Parisod, C. and Pratta, G. R.
}

DOI: $10.31047 / 1668.298 x . v 38 . n 2.33260$

\begin{abstract}
SUMMARY
Banana micropropagation for obtaining free-virus plants frequently provokes somaclonal variation that could increase useful genetic variability in this asexually propagated crop. Both exploring the cycle of in vitro culture in which somaclonal variation occurs and the amount of generated polymorphism, are necessary. In this work, preliminary results of somaclonal variation during early cycles of banana in vitro culture are reported. Four randomly selected regenerated plants from the fifth cycle and two samples from the mother plant were analyzed. A total of 36 AFLP primer combinations were assayed, and 24 of them produced amplicons varying among 50-500 bp. The mother plant presented a total of 125 different amplicons while the regenerated plants jointly showed 131 different amplicons with a mean of $119.75 \pm 3.97$ per individual. High level of DNA polymorphism (24.43\%) was found among micropropagated plants and, additionally, the occurrence of somaclonal variation at earlier cycles was suggested by multivariate analysis of Principal Coordinates. In this study, somaclonal variation at early cycles of banana micropropagation was validated and the adequacy of AFLP technique to assess it at the molecular level was verified. The phenotypic effects of the detected somaclonal variations remain to be evaluated.
\end{abstract}

Key words: micropropagation, Musa spp., genetic variability, molecular breeding, Principal Coordinate Analysis

Ermini, J. L., Tenaglia, G. C., Parisod, C. y Pratta, G. R., 2021. Variación somaclonal en banana evaluada por los perfiles de polimorfismo en la longitud de los fragmentos amplificados en ciclos tempranos de cultivo in vitro. Agriscientia 38 (2): 143-148

\section{SUMMARY}

La micropropagación de banana para obtener plantas libres de virus frecuentemente provoca variación somaclonal que puede incrementar la variabilidad genética en cultivos de reproducción asexual. Es necesario explorar el ciclo del cultivo in vitro en que se produce esta variación así como cuantificar el porcentaje de polimorfismo. Este trabajo presenta resultados de variación 
somaclonal en ciclos tempranos de micropropagación de banana. Cuatro plantas tomadas al azar del quinto ciclo de regeneración y dos muestras de la planta madre se caracterizaron con 36 combinaciones de cebadores de AFLP. Veinticuatro combinaciones produjeron amplicones en un rango entre 50-500 pb. La planta madre presentó en total 125 amplicones mientras que en conjunto las plantas regeneradas mostraron 131 amplicones, con una media de 119,75 $\pm 3,97$ por individuo. Se detectó un alto porcentaje de polimorfismo $(24,43 \%)$ en las plantas micropropagadas y, adicionalmente, análisis multivariados de coordenadas principales sugirieron la ocurrencia de variación somaclonal en ciclos de regeneración anteriores. En este estudio se validó la ocurrencia de variación somacloanl en ciclos tempranos de la micropropagación en banana y se verificó que la técnica de AFLP es adecuada para evaluarla a nivel molecular. Queda pendiente evaluar los efectos fenotípicos de estas variantes somaclonales.

Palabras clave: micropropagación, Musa spp., variabilidad genética, mejoramiento vegetal molecular, análisis de coordenadas principales

Ermini, J. L. (ORCID: 0000-0002-7789-3439): Doctorando en Ciencias Agrarias, Secretaría de Posgrado, Facultad de Ciencias Agrarias, Universidad Nacional de Rosario, CC14 S2125ZAA Zavalla, provincia de Santa Fe, Argentina. Tenaglia, G. C. (ORCID: 0000-0002-00477664): INTA Centro Regional Chaco-Formosa, Laguna Naineck, Formosa, Argentina. Parisod, C. (ORCID: 0000-0001-8798-0897): Ecological Genomics, Institute für Pflanzenwissenschaften, Universität Bern, Altenbergrain 21, 3013 Bern, Schweizerische Eidgenossenscha. Pratta, G. R. (ORCID: 0000-0002-3682-0946): Instituto de Investigaciones en Ciencias Agrarias de Rosario (Universidad Nacional de Rosario, Consejo Nacional de Investigaciones Científicas y Técnicas), Facultad de Ciencias Agrarias, Campo Experimental J. F. Villarino, CC 14, S2125ZAA Zavalla, Argentina. Correspondence to: gpratta@unr.edu.ar

\section{INTRODUCTION}

Bananas and plantains (Musa spp. L) are monocotyledonous, perennial herbs, cultivated in more than 130 countries in the tropics and subtropics (Resmi and Ashalatha 2007). Bananas and plantains are a good source of carbohydrates, minerals and vitamins (Kodym and Zapata-Arias, 1998). The most cultivated banana is propagated asexually because of the sterility of most edible varieties due to triploidy, hence the genetic base is narrow and diversity depends on somatic mutation to confront new resistance to fungal, bacterial and viral pathogens and numerous pests (Menon, 2016; Razani et al., 2019; Carrera et al., 2021; Rebouças et al., 2021). Since 2010 banana consumption has remained flat on a global basis at around $15 \mathrm{~kg}$ per capita per year. The micropropagation technology is considered to produce plants of potential superior quality. Isolation of useful variants for quality traits in high yielding genotypes, improved disease resistance and stress tolerance performance, and the possibility of rapid multiplication of a valuable genotype are some advantages of in vitro plant tissue culture (Suman, 2017).

In Argentina, Formosa province is an important banana producer in a suboptimal geographical area. Hence, somaclonal variation could increase genetic variability by obtaining plants with better adaptability to the rigorous climate for this fruit in this subtropical region. Previous to this practical application, it is necessary to evaluate the period of somaclonal occurrence during micropropagation and its frequency in Argentinian conditions, given that biotic and abiotic factors affecting the growth and development of explant donor plants can modify the in vitro culture response. In order to asses somaclonal variation, the objective of this exploratory research was to characterize through Amplified Fragment Length Polymorphism (AFLP) four regenerated banana plants from the fifth cycle of in vitro culture together with two samples of the mother plant as a reference. 


\section{MATERIALS AND METHODS}

In the present study, the banana clone $\mathrm{BCCl}$, provided by INTA Chaco-Formosa collection, was micropropagated. Four samples randomly taken from a batch of 32 explants at the fifth cycle of in vitro regeneration were analysed, together with 2 samples of the mother plant, with 36 combinations of AFLP primers to reveal somaclonal variation. First, the explant $\left(1 \mathrm{~cm}^{3}\right)$ was excised from the decapitated shoot apex of $\mathrm{BCCl}$ and cultured following the standard protocol for in vitro initiation (Bairu et al., 2006) with $2 \mathrm{mg} \mathrm{l}^{-1}$ BAP, $0.023 \mathrm{mg} \mathrm{l}^{-1}$ of IBA, and $5.6 \mathrm{~g} \mathrm{l}^{-1}$ agar. Then, after one week in dark chamber and two weeks under light photoperiod, the growing shoot was cut in four pieces, each of them being transferred to the multiplication medium (Figure 1) composed by $5 \mathrm{mg} \mathrm{l}^{-1}$ of $\mathrm{BA}$ and $0.18 \mathrm{mg} \mathrm{I}^{-1}$ of IAA. Cultures were incubated at $22 \pm 2^{\circ} \mathrm{C}$ under a 12 hours photoperiod provided by continuous cool-white fluorescent lights. After 21 days, and during four additional cycles, multiplied shoots were isolated following the previous method mentioned and transferred to new tubes with fresh multiplication medium. The average number of shoots produced was 4, 9, 9, 23 and 32 at the first, second, third, fourth and fifth cycle, respectively.
Four plants of these 32 total regenerated at the fifth cycle were randomly chosen for molecular characterization together with two samples of the mother plant. The AFLP protocol described by Senerchia et al. (2015) was followed with minor modifications. First, the extracted genomic DNA was labeled in $1 \%(\mathrm{wt} / \mathrm{vol})$ agarose gel and run with TAE buffer at 80 Volts for 40 minutes. Visualization was achieved by using ethidium bromide stain to measure the quality. The quantity was evaluated

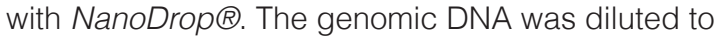
200-500 ngand digested with 8 units of EcoRI and 2 units of Msel in a final volume of $15 \mu \mathrm{L}$ incubated at $37^{\circ} \mathrm{C}$ for 2 hours and 20 minutes at $65^{\circ} \mathrm{C}$. Ligation of the digested fragments to the specific universal EcoRI and Msel adapters, both at final concentration of $0.14 \mathrm{pM}$, was achieved by incubation at $37^{\circ} \mathrm{C}$ for 2 hours with 1 unit of T4 ligase in a final volume of $35 \mu \mathrm{L}$. Pre-amplification samples were prepared with $1 \mu \mathrm{l}$ of the digested-ligated DNA, $5 \mathrm{mM}$ of each primer+1 (EcoRI+1: 5'-GACTGCGTACCAATTCA-3' and Msel+1: 5'-GATGAGTCCTGAGTAAC-3'), $10 \mathrm{mM}$ dNTPs, and 0.5 unit of Taq polymerase in a final volume of $20 \mu$ l. The PCR conditions were 28 cycles of 45 seconds at $94^{\circ} \mathrm{C}, 45$ seconds at $56^{\circ} \mathrm{C}$ and $1 \mathrm{~min}$ at $72^{\circ} \mathrm{C}$ each one. Once preamplified, the solution was 1:20 diluted in sterile water. The

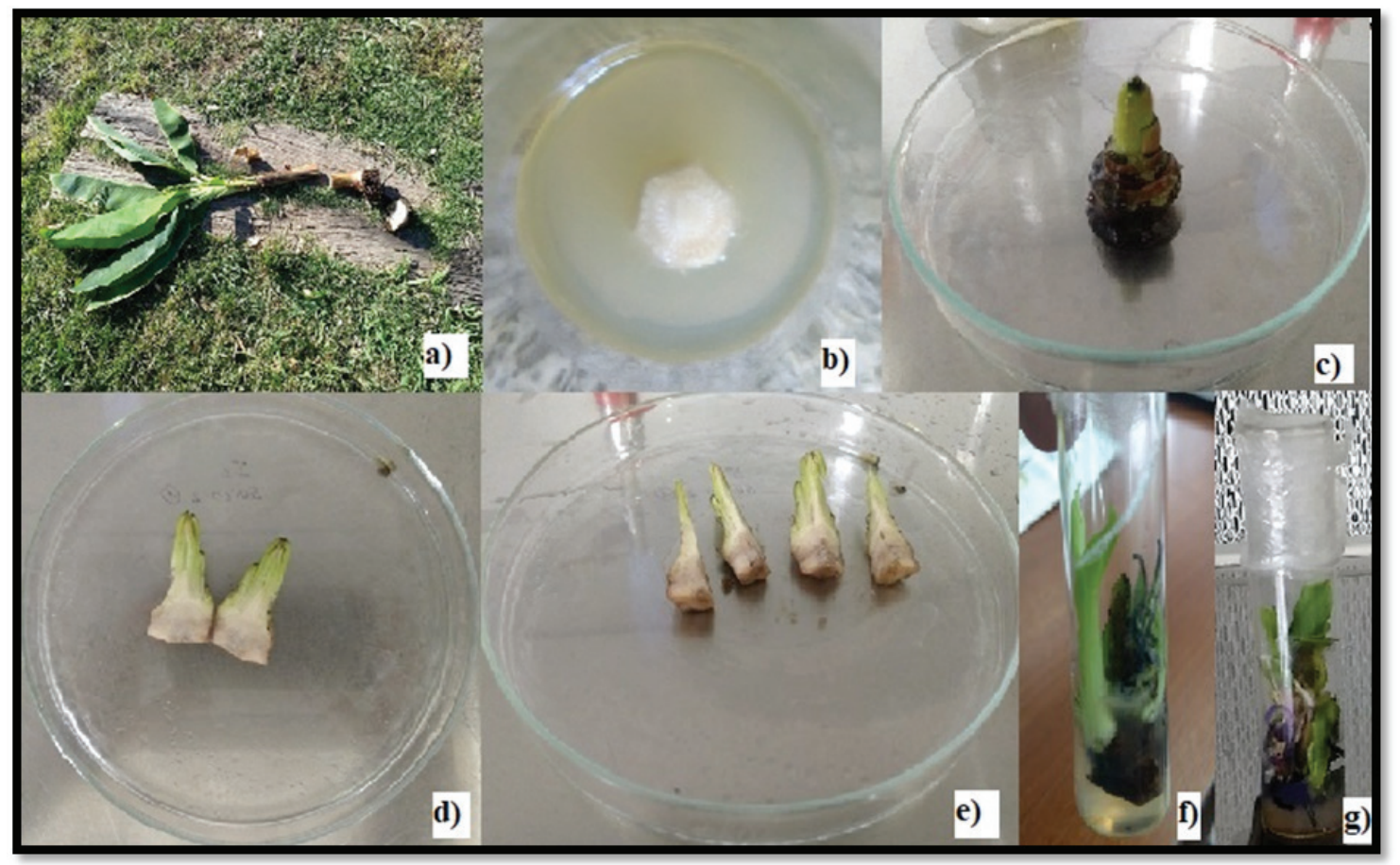

Figure 1. a) Source of explant from the mother plant BBC1 clone after one day of dehydration. b) BCCl explant in the initiation medium. c) Shoot grown from the unitiated explant before being cut for transferring to the multiplication medium. d) Cut of the shoot for disabling the apical dominance. e) First four explants for culturing in the multiplication medium. f) Shoot multiplication after 21 days in the first cycle of in vitro culture, g) Examples of shoot multiplication in following cycles of micropropagation 
selective amplification samples were prepared using $3 \mu \mathrm{l}$ of this dilution and the same mix used for pre-amplification. In the present study, 36 primers combinations of the primers +3 presented in Table 1 were assayed. A touchdown PCR for selective amplifications was programmed, starting with a cycle of 30 seconds at $94^{\circ} \mathrm{C}, 30$ seconds at $65^{\circ} \mathrm{C}$ and 1 minute at $72^{\circ} \mathrm{C}$. During the next 10 cycles, the annealing temperature was reduced to $-0.7^{\circ} \mathrm{C}$ per cycle, until reaching $56^{\circ} \mathrm{C}$. Then, 23 cycles of 30 seconds at $94^{\circ} \mathrm{C}, 1 \mathrm{~min}$ at $56^{\circ} \mathrm{C}$ and 1 minute at $72^{\circ} \mathrm{C}$ each were repeated.

As fluorophore-labelled primers NED ${ }^{\mathrm{TM}}$, VIC ${ }^{\mathrm{TM}}$, and $\mathrm{FAM}^{\mathrm{TM}}$ were used, the amplified bands, or amplicons, were resolved through fragment analysis capillary electrophoresis by ABI3730XL sequencer Macrogen ${ }^{\mathrm{TM}}$. Amplicons were analyzed using the GeneMarker ${ }^{\circledR}$ program. Monomorphic and polymorphic amplicons of molecular weights ranging from 500 and 50 base pairs were recorded in the samples analyzed. Polymorphic amplicons were identified according to their presence or absence in each sample, assigning values of 1 or 0 , respectively. The two samples taken from the mother plant were the reference for estimating the repeatability of the molecular characterization and then the reliability of the putative polymorphism in the regenerated plants. The number of total and polymorphic amplicons was recorded and the percentage of polymorphism was calculated. Finally, a binary matrix of $1 / 0$ was constructed and analyzed by Principal Coordinates Analysis with InfoGen software (Balzarini and Di Rienzo, 2003).

\section{RESULTS AND DISCUSSION}

Twenty four of the 36 AFLP primer-3 combinations were successful to generate molecular profiles. A total of 131 amplicons were obtained, 99 of them being monomorphic among the mother and the regenerated plants. An example of these results is shown in Figure 2. Hence a $24.43 \%$ of polymorphism was detected. Both BCC1, the mother plant, samples presented 125 amplicons and their AFLP profiles were identical. Instead, the four regenerated plants presented a total of 131 amplicons but their AFLP profiles were different. Some amplicons were common but others were specific of each individual. Hence, the mean number of amplicons per individual was $119.75 \pm 3.97$.

Regarding multivariate analysis, the first two Principal Coordinates accounted for a $71.1 \%$. The biplot generated from both these coordinates is shown in Figure 3. A different position of the mother and the regenerated plants according to their molecular polymorphism assessed by AFLP profiles can be observed in the biplot. In fact, the regenerated plants 48 and 57 from the fifth cycle of in vitro culture are next to each other and closer to both mother plant samples than the regenerated plants 67 and 70 . Interestingly, regenerated plants 48 and 57 were derived from the same regenerated plant 5 in the second cycle of in vitro culture while regenerated plants 67 and 70 were derived from the same regenerated plant 6 in the same second cycle. According to these observations, somaclonal variation has probably initiated at the earliest cycles of micropropagation and continued occurring during the subsequent cycles of in vitro culture. Additionally, the hypothesis about the occurrence of somaclonal variations at earlier cycles of in vitro culture is supported by observations from Youssef et al. (2011). In that report, authors analyzed somatic embryogenesis in 'Williams' and 'Great Dwarf' banana cultivars and reported the absence of 10 and 5 bands in the regenerated plants from a first cycle of in vitro culture assessed by AFLP when compared to the explant donors.

In a previous work using the standard AFLP technique(Erminietal., 2018), 6 primercombinations

Table 1. Primers +3 used for selective amplifications

\begin{tabular}{lccc}
\hline Msel (primer) 5' $\rightarrow$ 3' $^{\prime}$ & +3 bp ending & EcoRl (primer) 5' $\rightarrow$ 3' & +3 bp ending \\
\hline GATGAGTCCTGAGTAA & CAG & GACTGCGTACCAATTC & ACT \\
GATGAGTCCTGAGTAA & CTC & GACTGCGTACCAATTC & ACC \\
GATGAGTCCTGAGTAA & CCC & GACTGCGTACCAATTC & AGC \\
GATGAGTCCTGAGTAA & CGT & GACTGCGTACCAATTC & ATG \\
GATGAGTCCTGAGTAA & CCT & GACTGCGTACCAATTC & AAT \\
GATGAGTCCTGAGTAA & CGG & GACTGCGTACCAATTC & ATA \\
GATGAGTCCTGAGTAA & CTT & GACTGCGTACCAATTC & AAC \\
& & GACTGCGTACCAATTC & AAA \\
& & GACTGCGTACCAATTC & AAG \\
\hline
\end{tabular}




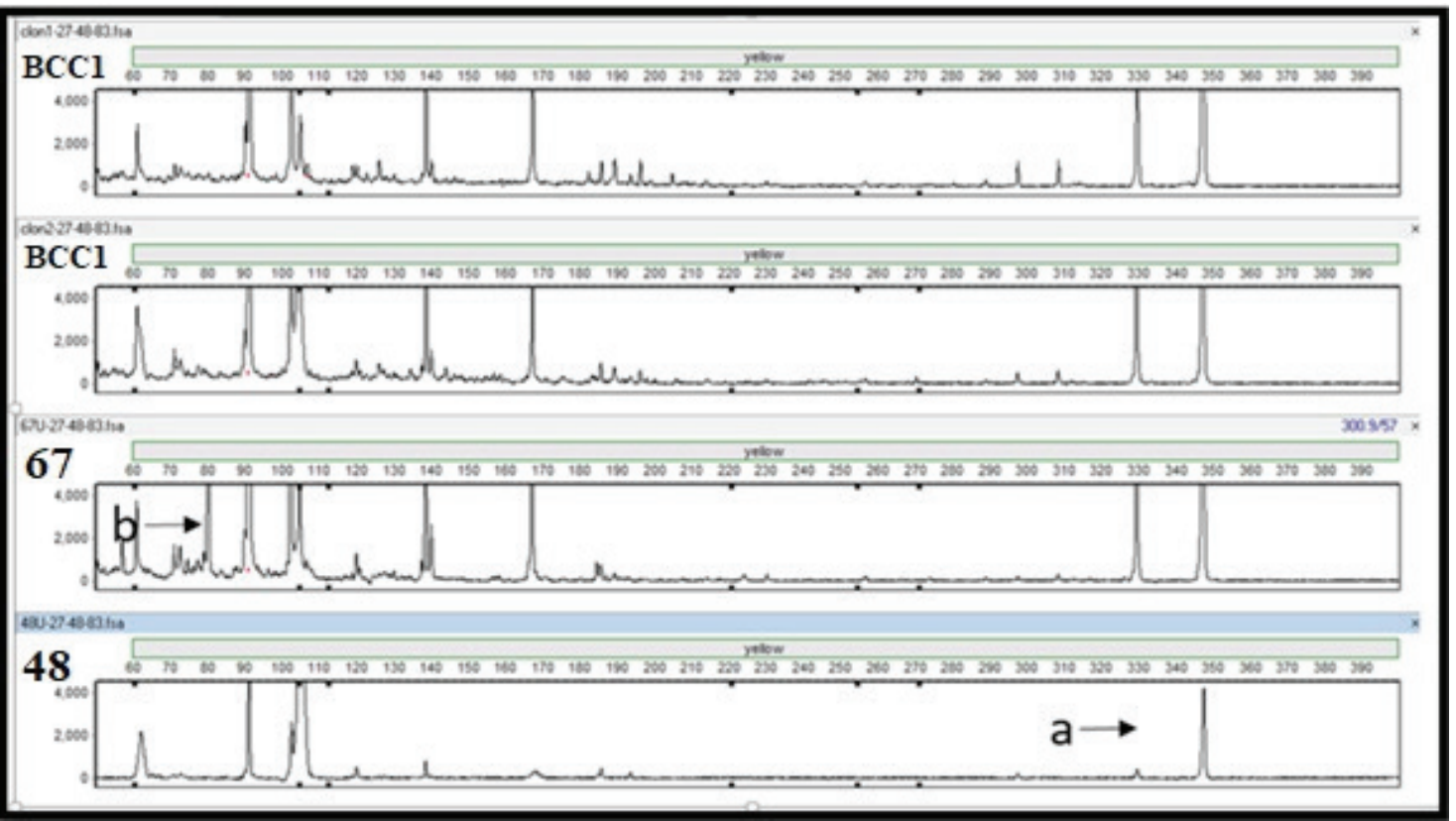

Figure 2. Example of AFLP analysis for assessing somaclonal variation at the molecular level. The two first rows show the AFLP profiles of the two samples from the mother plant. The two last rows show the AFLP profiles of regenerated plants 67 and 48 from the fifth cycle of in vitro culture. Arrows identified with letter "a" in the profile of plant 48 and with letter "b" in the profile of plant 67 show molecular polymorphisms compared to the mother plant and also among regenerated plants

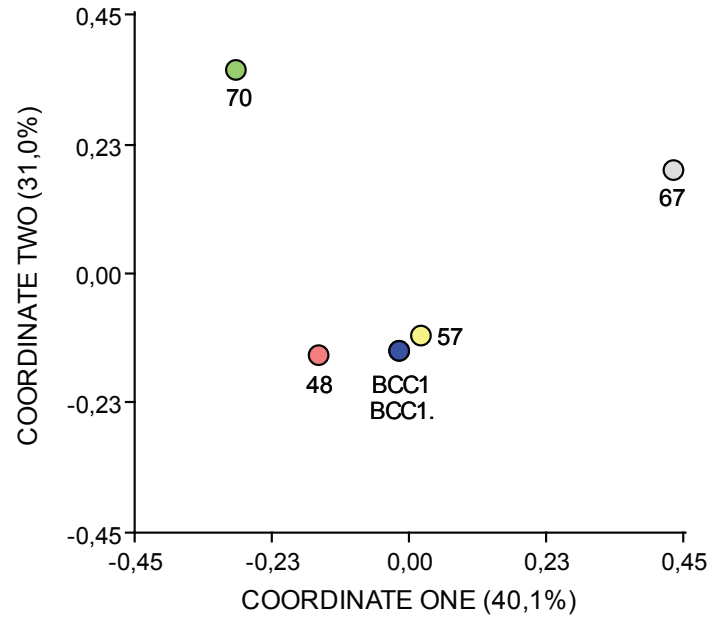

Figure 3. Biplot from Principal Component Analysis with all AFLP amplicons. Mother plant samples are identified as $\mathrm{BCCl}$ and $\mathrm{BCCl}$., respectively, and 48, 57, 67, and 70 are regenerated plant from the fifth cycle of in vitro culture

were successful to asses the genetic diversity of 52 genotypes selected for their interesting agronomic performance in the subtropical and suboptimal environment of the Argentinian Formosa province. The mother plant $\mathrm{BCCl}$ was included among these clones and the amount of genetic diversity detected in that work (100\%) was similar to the $95.50 \%$ of polymorphism reported by Opara et al. (2010). However, regenerated plants usually present more molecular polymorphism than unregenerated plants, as informed by Bairu et al. (2006), Deepthi et al. (2007) and the present study.

As a conclusion, this study validated the occurrence of somaclonal variation at early cycles of banana micropropagation and verified the adequacy of the AFLP technique to assess it at the molecular level. The phenotypic effects of the detected somaclonal variations remain to be evaluated.

\section{ACKNOWLEDGEMENTS}

Authors are grateful to Universidad Nacional de Rosario for partially financing this research from PID AGR 262 (2016) Caracterización molecular y micropropagación de clones selectos de banana.

\section{BIBLIOGRAPHY}

Bairu, M. W., Fennell, C. W. and van Staden, J. (2006). The effect of plant growth regulators on somaclonal variation in Cavendish banana (Musa AAA cv. 'Zelig'). Scientia Horticulturae, 108(4), 347-351. https://doi. 
org/10.1016/j.scienta.2006.01.039

Carrera, F. P., Noceda, C., Maridueña-Zavala, M. G., García, J. A., Ruiz-Barzola, O. and Cevallos-Cevallos, J. M. (2021). Changes in the metabolite profile during micropropagation of normal and somaclonal variants of banana Musa AAA cv. Williams. Horticulturae, 7(3), 39. https://doi.org/10.3390/horticulturae7030039

Deepthi, V. P., Simon, L. and Narayanaswamy, P. (2007). Identification of elite somaclonal variants from tissue cultured Grand Naine banana (Musa spp. AAA) types using RAPDs. Fruit, Vegetable and Cereal Science and Biotechnology Journal, 1(2), 116-120.

Balzarini, M. and Di Rienzo, J. (2003) Info-Gen: Software estadístico para análisis de datos genéticos. Facultad de Ciencias Agropecuarias. Universidad Nacional de Córdoba. Argentina. https://www.info-gen.com.ar/

Ermini J. L., Tenaglia, G. and Pratta, G. R. (2018). Molecular diversity in selected banana clones (Musa AAA "Cavendish") adapted to the subtropical environment of Formosa Province (Argentina). American Journal of Plant Sciences, 9(12), 2504-2513. https://doi.org/10.4236/ajps.2018.912181

Kodym, A. and Zapata-Arias, F. J. (1998) Natural light as an alternative light source for the in vitro culture of banana (Musa acuminata cv 'Grande Naine'). Plant Cell Tissue and Organ Culture 55, 141-145. https://doi. org/10.1023/A:1006119114107

Menon, R. (2016). Banana breeding. In S. Mohandas and K. Ravishankar (Eds.), Banana: genomics and transgenic approaches for genetic improvement (1344). Springer.

Opara, U. L., Jacobson, D. and Al-Saady, N. A. (2010). Analysis of genetic diversity in banana cultivars (Musa cvs.) from the South of Oman using AFLP markers and classification by phylogenetic, hierarchical clustering and principal component analyses. Journal of Zhejiang University- Science B, 11(5), 332-341. https://doi.org/10.1631/jzus.B0900310

Razani, M., Kayat, F., Redwan, R. M. and Susanto, D. (2019). Effect of somaclonal variation in Musa acuminata cv. Berangan through micropropagation using RAPD. Biotechnology, 18, 9-14. https://doi. org/10.3923/biotech.2019.9.14

Rebouças, T. A., de Jesus Rocha, A., Sousa Cerqueira, T., Ramalho Adorno, P., Queiroz Barreto, R., dos Santos Ferreira, M., Souza Morais Lino, L., Batista de Oliveira Amorim, V., Almeida dos Santos-Serejo, J., Haddad, F., Fortes Ferreira, C. and Perito Amorim, E. (2021). Preselection of banana somaclones resistant to Fusarium oxysporum f. sp. cubense, subtropical race 4. Crop Protection, 147, 105692. https://doi.org/10.1016/j. cropro.2021.105692

Resmi, L. and Ashalatha, N. S. (2007). Plantlet production from the male inflorescence tips of Musa acuminata cultivars from South India. Plant Cell, Tissue and Organ Culture, 88, 333-338. https://doi.org/10.1007/ s11240-007-9206-7

Senerchia, N., Felber, F. and Parisod, C. (2015). Genome reorganization in $\mathrm{F} 1$ hybrids uncovers the role of retrotransposons in reproductive isolation. Proceedings of the Royal Society, 282(1804). http:// doi.org/10.1098/rspb.2014.2874

Suman, S. (2017). Plant tissue culture: A promising tool of quality material production with special reference to micropropagation of banana. Biochemical Cell Architecture, 17 (1), 1-26.

Youssef, M., Ku-Cauich, R., James, A. and Escobedo Gracia Medrano, R. M. (2011) Genetic analysis of somatic embryogenesis derived plants in banana. Assiut Journal of Agricultural Sciences, 42(Special Issue), 287-300. 